\title{
Neonatal Hypoxic-Ischemic Brain Injury Leads to Sex-Specific Deficits in Rearing and Climbing in Adult Mice
}

\author{
Zdeněk LAŠTƯVKA ${ }^{1}$, Veronika BORBÉLYOVÁ ${ }^{2}$, Kateřina JANIŠOVÁ ${ }^{\mathbf{1}}$, Jakub OTÁHAL ${ }^{\mathbf{3}}$, \\ Jaromír MYSLIVEČEK ${ }^{1}$, Vladimír RILJAK ${ }^{1}$ \\ ${ }^{1}$ Institute of Physiology, First Faculty of Medicine, Charles University, Prague, Czech Republic, \\ ${ }^{2}$ Institute of Molecular Biomedicine, Faculty of Medicine, Comenius University, Bratislava, Slovak \\ Republic, ${ }^{3}$ Laboratory of Developmental Epileptology, Institute of Physiology of the Czech \\ Academy of Sciences, Prague, Czech Republic
}

Received March 30, 2020

Accepted October 19, 2020

\section{Summary}

The study examined the morphological and long-term behavioral impacts of neonatal hypoxic-ischemic brain injury in a mouse model. We investigated the modification of different behavioral domains, such as spontaneous climbing, which represents fine motor skills. We also focused on sex-dependent differences during hypoxic-ischemic encephalopathy. The Rice-Vannucci model of hypoxia-ischemia was used, adjusted and adapted to 7-day-old C57BL/6NTac mice. The effects of induced hypoxia and ischemia were also studied separately. At postnatal day 60 , mice underwent behavioral testing using the LABORAS apparatus. The perfusion for histological evaluation was performed one day after the behavioral analyses. In groups with separately induced hypoxia or ischemia, the observed alterations in behavior were not accompanied by morphological changes in the cortex or hippocampal formation. Female mice naturally climbed significantly more and hypoxic females reared less than hypoxic males $(p<0.05)$. Male mice postnatally exposed to hypoxiaischemia exhibited significantly lower vertical activity and higher horizontal activity $(p<0.05)$. Mild hypoxic damage may not be morphologically detectable but may induce substantial behavioral changes in adult mice. There were significant differences between horizontal and vertical activity in reaction to hypoxiaischemia. Our study indicates that the importance of behavioral testing is irreplaceable and may be reflected in neonatal medicine.

\section{Key words}

Newborn • Mouse • Hypoxia-ischemia • Open-field test • Sex differences

\section{Corresponding author}

V. Riljak, Institute of Physiology, First Faculty of Medicine, Charles University, Prague, Czech Republic. E-mail: vladimir.riljak@lf1.cuni.cz

\section{Introduction}

Despite extensive ongoing research in neonatalperinatal medicine, hypoxic-ischemic (HI) injury in utero or during birth remains an alarming health and economic problem (Hagberg et al. 2016, Tagin et al. 2015). It is associated with approximately $25 \%$ of global neonatal deaths (Liu et al. 2015). Perinatal asphyxia currently affects 3 to 5 of every 1000 full-term live births, and approximately $20 \%$ of these neonates experience severe hypoxic-ischemic encephalopathy (HIE) (Colver et al. 2014, Derrick et al. 2012). Cognitive impairment, spatial memory changes (Biswal et al. 2016), depression-like behavior, seizures (Shetty 2015) and deficits in locomotor performance (Vannucci and Hagberg 2004) are some of the consequences that affect children who suffered perinatal HIE. The pathophysiological mechanisms of HI injury are divided into three phases (Douglas-Escobar and Weiss 2015, Murden et al. 2019). The first phase is a primary energy failure due to an $\mathrm{HI}$ insult, such as depletion of ATP, inefficient anaerobic metabolism, ATP-dependent $\mathrm{Na} / \mathrm{K}$ pump failure, accumulation of lactic acid and hypoxanthine, membrane depolarization, accumulation of excitatory amino acids, intracellular entry of water, sodium and calcium, cell edema and early 
cell death. The second phase includes the consequences of reoxygenation and reperfusion: increased production of radical oxygen species, higher level of intracellular calcium, mitochondrial dysfunction, increased expression of pro-inflammatory genes, and late cell death. The third phase is initiated if the previous events worsen and inflammation becomes a chronic process (DouglasEscobar and Weiss 2015, Murden et al. 2019). All of these events lead to a detrimental brain injury that ultimately results in the clinical picture of HIE. An effective causal therapy for HIE is not available, except therapeutic hypothermia (Davidson et al. 2015, Perlman et al. 2010). Therefore, there is a continuous and unmet need for an adequate model of HIE that represents the complex clinical picture relevant to humans (Northington 2006). It is essential to use a live model to approximate the real perinatal conditions of human newborns. The most promising model is the RiceVannucci model (Rice et al. 1981, Vannucci and Hagberg 2004) adjusted and adapted for mouse (Ditelberg et al. 1996, Zhu et al. 2009). This model simulates brain damage patterns and motor deficits that are similar to humans. The model also allows investigations of new methods of brain damage prevention and repair at the cellular (e.g. introduction of pharmacological or biotechnological agents that interrupt the cascade of pathophysiological events) and systemic levels (e.g. stem cell transplantation) (Riljak et al. 2016, Rumajogee et al. 2016). The clinical manifestations are accompanied by unilateral morphological damage of the brain tissue and impaired neocortical cytoarchitecture (Vannucci and Hagberg 2004). However, the general evaluations of mouse locomotor activity in an open field arena may fail to consider some of the important aspects of mouse behavior. One of the overlooked aspects is the presence and duration of climbing in mice (Borbélyová et al. 2019). The introduction of a roof in the open field arena provides an opportunity to detect and evaluate the soft grip needed to hold onto the arena cage bars. Therefore, changes in climbing are a valuable representation of fine motor impairment. The roof bars represent the closest connection to the surrounding environment, and this new element in the testing field examines the willingness of mice to explore and escape from captivity (Nevison et al. 1999, Pietropaolo et al. 2007). Previous animal studies reported gender-dependent differences in reaction to hypoxia (Hill and Fitch 2012, Huang et al. 2016, Sanches et al. 2015). Male infants exhibited an increased risk to $\mathrm{HI}$ events and greater behavioral and cognitive disruption
(Johnston and Hagberg 2007, Lan et al. 2011). Our study used the Rice-Vannucci model of unilateral hypoxiaischemia in 7-day-old mice. Seven-day-old mice approximately equal human newborns (Clowry et al. 2014, Gennaro et al. 2019, Rumajogee et al. 2016, Sheldon et al. 2018). The effects of induced hypoxia and ischemia were also studied separately. We examined the $\mathrm{HI}$ consequences on the spontaneous home-cage behavior of adult mice and their ability to cope with a novel environment. We also investigated how hypoxia-ischemia modified the presence of different behavioral domains, such as spontaneous climbing, and whether these behavioral differences were sex-dependent.

\section{Methods}

\section{Animals and housing conditions}

The current study used C57Bl/6NTac mice (total: $n=69$, males: $n=42$, females: $n=27$ ). The parent animals originated from the Centre for Experimental Biomodels, First Faculty of Medicine, Charles University, Prague. Following an acclimatization period, the parental mice were mated overnight. Pregnant females were housed individually. The mothers were caged with their offspring until weaning on postnatal day 21 (PND21). All mice were kept in a controlled environment (temperature $22 \pm 2{ }^{\circ} \mathrm{C}$, humidity $55 \pm 10 \%$, 12:12-hour light-dark cycle) with ad libitum access to food and water. All experiments were performed between 08:00 and 12:00 when mother was less active and stayed in the nest to keep the pups warm after the surgery/hypoxia induction. Animals were treated in accordance with the legislature of the Czech Republic and the EU legislature [European Convention for the Protection of Vertebrate Animals used for Experimental and other Scientific Purposes (Council of Europe No. 123, Strasbourg 1985)], and the experimental protocol was approved by the Committee for the Protection of Experimental Animals of the First Medical Faculty, Charles University, Prague and by the Ministry of Education of the Czech Republic under No. MSMT11196/2020-2.

\section{Hypoxic-ischemic brain injury induction}

The Rice-Vannucci model (Rice et al. 1981) was adjusted and adapted to mouse (Ditelberg et al. 1996, Zhu et al. 2009). Seven-day-old mouse pups underwent unilateral ligation of the common carotid artery in combination with exposure to $8 \%$ oxygen hypoxic air. 
Mice were divided into four groups: the first group underwent the ligation of the carotid artery and the exposure to hypoxia $[\mathrm{CA} / \mathrm{H}]$ (i.e. the Rice-Vannucci model); the second group underwent only the ligation of the carotid artery [CA/-]; the third group underwent only the exposure to hypoxia $[-/ \mathrm{H}]$; and the last group served as the control group with no ligation of the carotid artery nor exposure to hypoxia [-/-].

\section{Surgery procedure}

On postnatal day 7 (PND7), mouse pups underwent the surgical procedure. Body temperature was maintained at $36.5^{\circ} \mathrm{C}$ using a heating pad. Mice were anesthetized with isoflurane using a nasal mask $(5.0 \%$ for induction and $2.0 \%$ for maintenance), then gently fixated on their back using micropore surgical tape. The target area of the skin was disinfected with a $10 \%$ povidone-iodine solution, and a $0.3-\mathrm{cm}$ incision was made on the neck close to midline using scissors. Fat and muscles were carefully pushed away using fine-tip forceps. Close to the midline, underneath the fat and muscles, the right common carotid artery was identified for ligation. The artery was carefully dissected free from the vein, the vagal nerve and other surrounding soft tissues using fine-tipped forceps and ligated via electrocoagulation (Electrosurgical unit 1E, KENTAMED Ltd., Plovdiv, Bulgaria). After the ligation, the wound was closed using 6-0 suture. After the surgical procedure, the pups were put on the heating plate to recover from anaesthesia. After the recovery, the pups were returned to their mother to rest for $1 \mathrm{~h}$. Mouse pups of the $[-/ \mathrm{H}]$ and $[-/-]$ group underwent the same procedure, except for ligation of the right common carotid artery. The surgical procedure lasted approximately $6 \mathrm{~min}$.

\section{Hypoxia induction}

After recovery from the surgery for $1 \mathrm{~h}$ with their dam, the pups were placed in a hypoxia chamber. Normal airflow through the chamber was maintained for 10 min. The flow was changed from regular air to $8 \%$ oxygen via mixing of the air with calibrated nitrogen (LINDE GAS a.s., Prague, Czech Republic) for $70 \mathrm{~min}$. The flow was changed from $8 \%$ oxygen back to regular air for $10 \mathrm{~min}$. The pups were removed from the hypoxia chamber and returned to their dam. During the entire procedure in the chamber, the temperature remained stable at $36{ }^{\circ} \mathrm{C}$. Mouse pups stayed with their mothers until weaning. Mouse pups of the $[\mathrm{CA} /-]$ and [-/-] groups underwent the same procedure, except for exposure to $8 \%$ oxygen.

\section{Behavioral testing}

Open field test (LABORAS system)

To assess the spontaneous behavior of mice and evaluate their ability to cope with novelty, we used the Laboratory Animal Behaviour Observation, TM Registration, and Analysis System (LABORAS ${ }^{\mathrm{TM}}$, Metris, Hoofddorp, Netherlands). LABORAS is an automated system for the continuous tracking of small rodent behavior. On PND60, the spontaneous behavior of mice was analysed. Mice were weighed and placed in the LABORAS system for $20 \mathrm{~min}$. The LABORAS system transforms the mechanical vibrations generated by the animal during locomotion, rearing (time spent standing on rear limbs to explore the environment) and grooming into electrical signals. These signals are processed, classified and compared with predetermined characteristic patterns by the LABORAS software (Van de Weerd et al. 2001). Spontaneous behavior was statistically analysed over successive 5-minute intervals (0-5 min, 5-10 min, 10-15 min, and 15-20 min). Each recorded behavioral parameter, such as the time spent in locomotion, time spent rearing, time spent climbing and the travelled distance, was evaluated separately. Throughout the 20-minute sessions, the animals were left undisturbed. Following the behavioral testing, the animals were returned to their home cages.

\section{Tissue processing}

For histological analyses, four male pups and four female pups from each study group were anaesthetised via an intraperitoneal injection of thiopental (40 mg/kg body weight) and immediately perfused transcardially. Transcardial perfusions were performed one day after behavioral analyses (i.e. PND61). Ice-cold saline $(0.9 \% \mathrm{NaCl})$ was used for transcardial perfusion, followed by fixation with ice-cold $4 \%$ paraformaldehyde (dissolved in 0.1 M phosphate buffer, $\mathrm{pH}$ 7.4). The brain was removed carefully from the skull of each animal and fixed in $4 \%$ paraformaldehyde overnight. Fixed brains were cryoprotected in a $20 \%$ sucrose solution for at least 1 day. Brains were sectioned at $-20{ }^{\circ} \mathrm{C}$ using a cryostat (Leica CM 3050S, Leica Biosystems, Nussloch, Germany), and every third $30-\mu \mathrm{m}$ thick section from each animal brain was collected to assess neuronal degeneration. The tissue sections were mounted on 
gelatinized slides and allowed to dry at room temperature.

\section{Nissl staining}

Each coronal section of the brain was stained with cresyl violet (Sigma-Aldrich, St. Louis, Missouri, USA). The mounted brain tissue sections were dehydrated in a graded series of ethanol $(70 \%, 80 \%$, and $96 \%$ ) for 2 min each and stained with a Nissl solution ( $1 \%$ cresyl violet, $0.2 \mathrm{~mol} / 1$ acetic acid, and $0.2 \mathrm{~mol} / 1$ sodium acetate, 4:1, $\mathrm{pH}=3$ ) for approximately $20 \mathrm{~min}$. When the desired color intensity was reached, the slices were washed twice in distilled water and a graded series of ethanol $(96 \%, 80 \%$, and $70 \%$ ) for 2 min each. Slides were immersed in xylene (Penta s.r.o., Prague, Czech Republic) for $5 \mathrm{~min}$. Slides were incubated in another xylene bath (for approximately $45 \mathrm{~min}$ ), mounted using Roti-Histokitt II mounting medium (Carl Roth $\mathrm{GmbH}+$ Co. KG, Karlsruhe, Germany) and cover-slipped. The following regions of brain tissue were analysed: cortex, CA1 and CA3 regions of the hippocampus, the hilus and the dorsal and ventral blades of the dentate gyrus.

\section{Statistical analysis}

Statistical analyses were performed using GraphPad Prism version 8 (GraphPad Software, Inc., CA, USA). To analyze the spontaneous behavior of the mice and detect sex differences, two-way analysis of variance (ANOVA) with Bonferroni-corrected post hoc t-test and nonparametric Mann-Whitney $\mathrm{U}$ tests were used. $\mathrm{P}$ values lower than 0.05 were considered statistically significant. The data are presented as the means \pm standard error of the mean (SEM).

\section{Results}

\section{Behavioral testing}

All three target male groups $[\mathrm{CA} / \mathrm{H}, \mathrm{CA} /-,-/ \mathrm{H}]$ spent more time in locomotion than controls: Two-way ANOVA revealed significant effects on time $(\mathrm{p}<0.001)$ and treatment $(\mathrm{p}<0.001)$ in $[\mathrm{CA} / \mathrm{H}]$ males. Bonferronicorrected post hoc $t$-test revealed significantly higher locomotor activity in $[\mathrm{CA} / \mathrm{H}]$ males between the $1^{\text {st }}$ and $5^{\text {th }}$ min of the open field test $(\mathrm{p}<0.05)$ (Fig. 1A). Two-way ANOVA showed a significant effect on time $(p<0.05)$ in $[C A / H]$ females (Fig. 1B). Significant effects on time $(\mathrm{p}<0.001)$ and treatment $(\mathrm{p}<0.01)$ were observed in $[\mathrm{CA} /-]$ males. Bonferroni-corrected post hoc $t$-test revealed significantly higher locomotor activity in $[\mathrm{CA} /-$ ] males between the $1^{\text {st }}$ and $5^{\text {th }}$ min of the open field test $(\mathrm{p}<0.05)$ (Fig. 1C). Two-way ANOVA showed a significant effect on time $(p<0.01)$ and treatment $(p<0.01)$ in females (Fig. 1D). A significant effect on time $(p<0.001)$ and interaction between these factors $(p<0.05)$ was observed in $[-/ \mathrm{H}]$ males. Bonferroni-corrected post hoc $t$-test revealed significantly higher locomotor activity in $[-/ \mathrm{H}]$ males between the $1^{\text {st }}$ and $5^{\text {th }}$ min of the open field test $(\mathrm{p}<0.01)$ (Fig. 1E).

Males in all observed groups $[\mathrm{CA} / \mathrm{H}, \mathrm{CA} /-$, -/H, -/-] explored the arena significantly more than females: Two-way ANOVA revealed a significant effect on time $(\mathrm{p}<0.01)$ in the $[\mathrm{CA} / \mathrm{H}]$ group (Fig. $1 \mathrm{G})$. A significant effect on time $(p<0.001)$ was also observed in the [CA/-] group (Fig. 1H). Significant effects on time $(p<0.001)$ and sex $(p<0.01)$ were observed in the $[-/ \mathrm{H}]$ group. Bonferroni-corrected post hoc $t$-test revealed significantly higher locomotor activity in $[-/ \mathrm{H}]$ males between the $1^{\text {st }}$ and $5^{\text {th }}$ min of the open field test $(\mathrm{p}<0.05)$ (Fig. 1I). Two-way ANOVA revealed a significant effect on time in the $[-/-]$ group $(\mathrm{p}<0.001)$ (Fig. 1J).

Males in the $[\mathrm{CA} / \mathrm{H}]$ group spent less time rearing compared to controls [-/-]: Two-way ANOVA showed a significant effect on treatment in $[\mathrm{CA} / \mathrm{H}]$ males $(\mathrm{p}<0.05)$ (Fig. 2A). Males of the $[\mathrm{CA} /-]$ and $[-/ \mathrm{H}]$ groups reared significantly more than females: There was a significant effect on time in the $[\mathrm{CA} /-]$ group $(\mathrm{p}<0.05)$ (Fig. 2H). The Mann-Whitney $U$ test revealed significance in the $[-/ \mathrm{H}]$ group $(\mathrm{p}<0.05)$ (Fig. 2I).

All three target male groups $[\mathrm{CA} / \mathrm{H}, \mathrm{CA} /-,-/ \mathrm{H}]$ explored the test arena significantly more than controls: Two-way ANOVA revealed significant effects on time $(\mathrm{p}<0.001)$ and treatment $(\mathrm{p}<0.01)$ in $[\mathrm{CA} / \mathrm{H}]$ males (Fig. 3A). Significant effects on time $(p<0.001)$ and treatment $(\mathrm{p}<0.01)$ were observed in $[\mathrm{CA} /-]$ males. Bonferroni-corrected post hoc $t$-test revealed significantly longer distances in $[\mathrm{CA} /-]$ males between the $1^{\text {st }}$ and $5^{\text {th }}$ min of the open field test $(\mathrm{p}<0.05)$ (Fig. 3C). Two-way ANOVA revealed a significant effect on time in $[-/ \mathrm{H}]$ males $(\mathrm{p}<0.001)$. Bonferroni-corrected post hoc $t$-test revealed significantly longer distances in $[-/ \mathrm{H}]$ males between the $1^{\text {st }}$ and $5^{\text {th }}$ min of the open field test $(\mathrm{p}<0.05) \quad$ (Fig. 3E). Two-way ANOVA showed a significant effect of treatment in $[-/ \mathrm{H}]$ females $(p<0.05)$ (Fig. 3F).

Males of all observed groups $[\mathrm{CA} / \mathrm{H}, \mathrm{CA} /-,-$ /H, -/-] explored the arena significantly more than hypoxic females: Two-way ANOVA revealed a significant effect on time in the $[\mathrm{CA} / \mathrm{H}](\mathrm{p}<0.05)$ and $[\mathrm{CA} /-](\mathrm{p}<0.001)$ groups (Fig. $3 \mathrm{G}$ and $\mathrm{H}$ ). Significant effects on time 


\section{COMPARED WITH - / -}
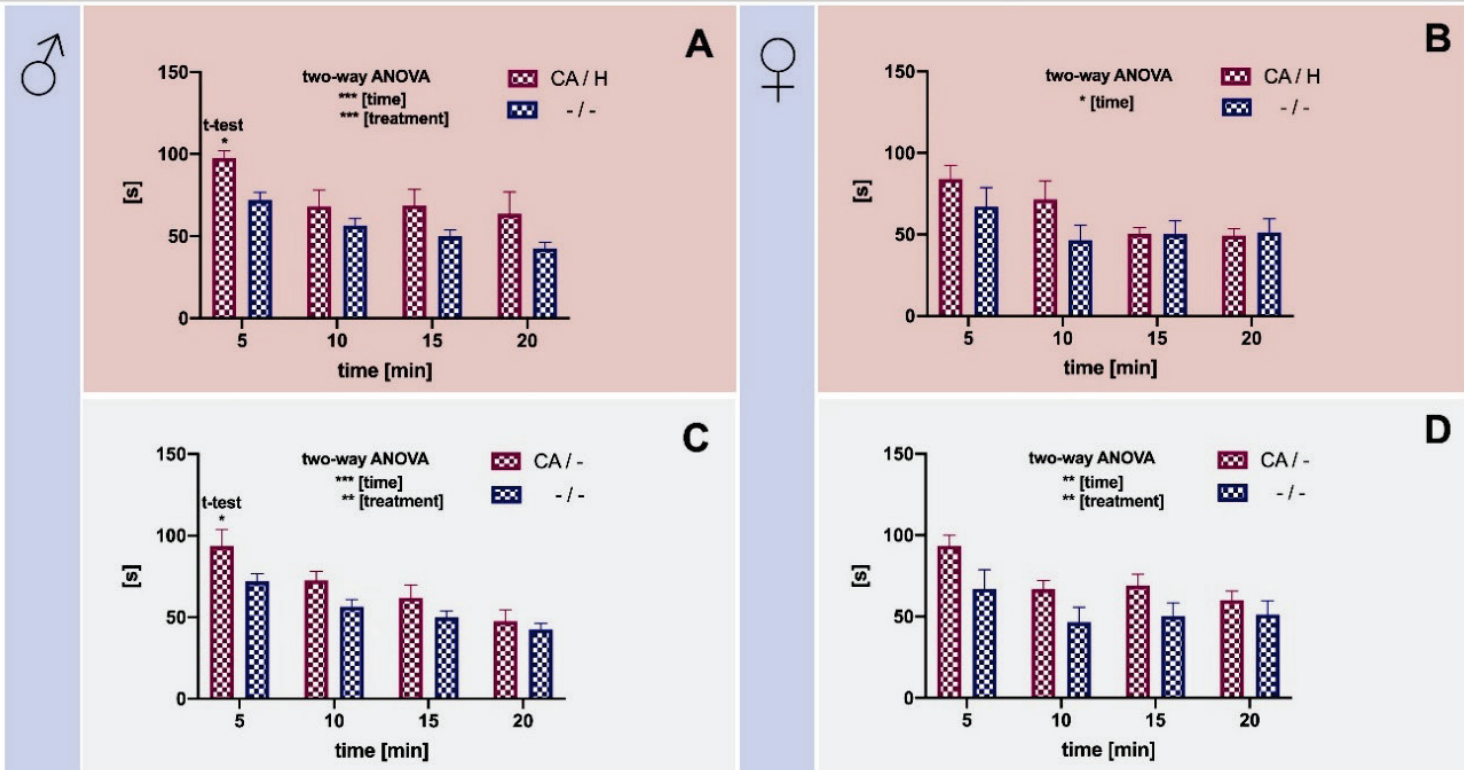

C
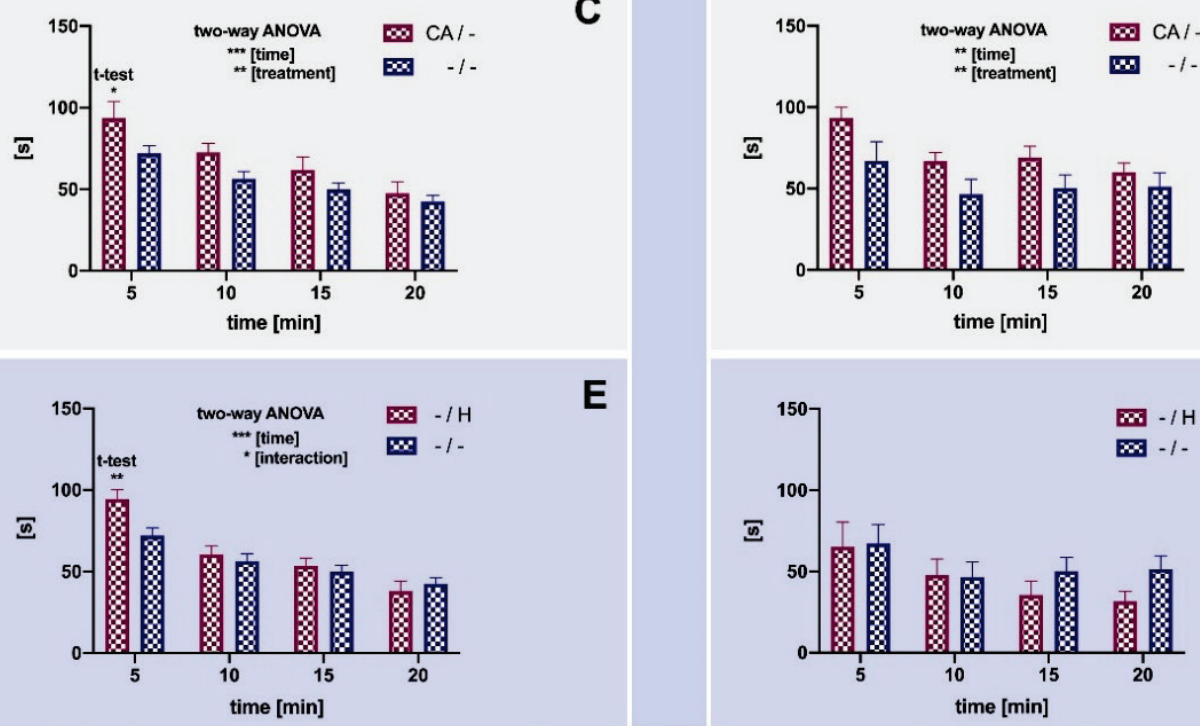

E

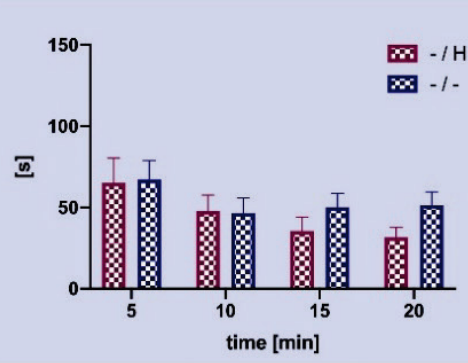

\section{SEX DIFFERENCES}
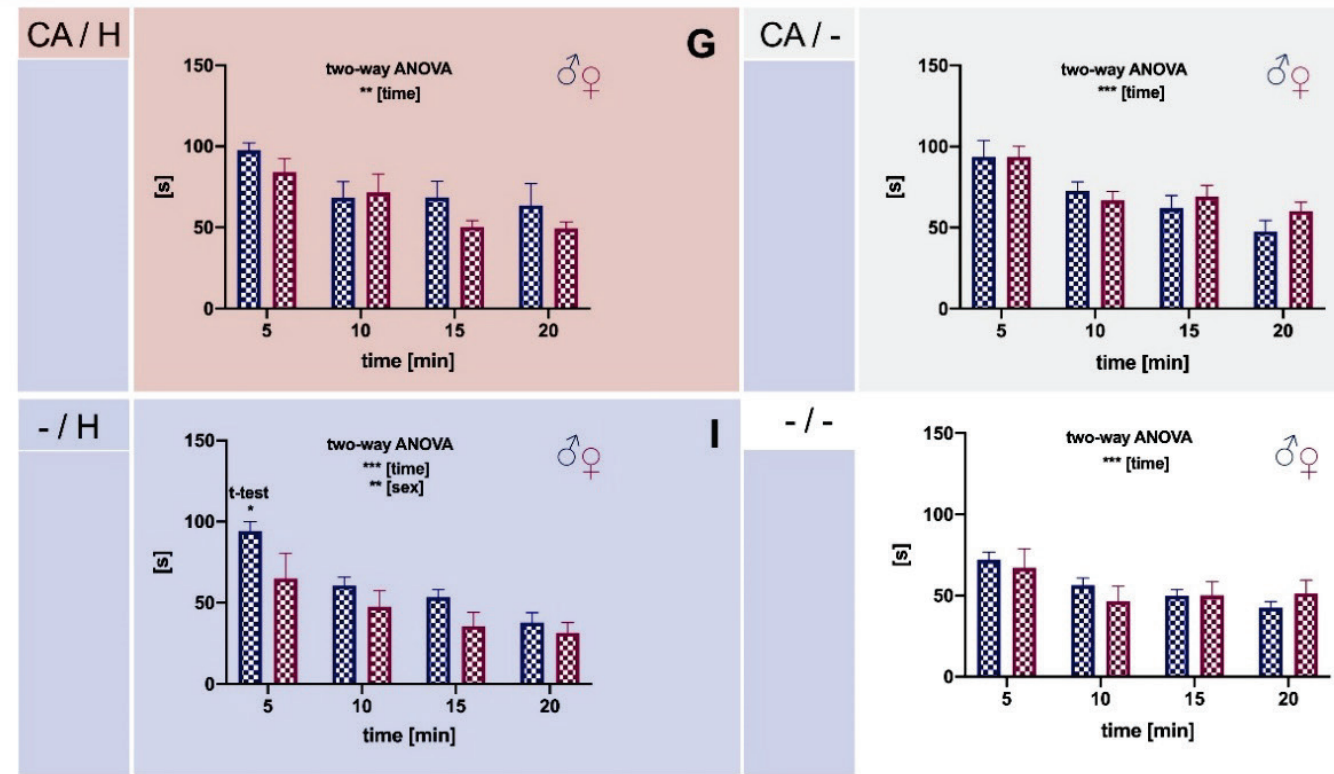

Fig. 1. Effect of early postnatal hypoxia and carotid artery ligation on locomotor activity in mice in the open field test. Panels $\mathbf{A}, \mathbf{B}, \mathbf{C}$, $\mathbf{D}, \mathbf{E}, \mathbf{F}, \mathbf{G}, \mathbf{H}, \mathbf{I}$ and $\mathbf{J}$ show locomotion duration in a particular 20-minute interval. $[C A / H]$ male $(A: n=4)$ and female $(B: n=7)$ mice compared to $[-/-]$ controls. [CA/-] male $(C: n=8)$ and female $(D: n=7)$ mice compared to [-/-] controls. $[-/ H]$ male $(E: n=14)$ and female $(F: n=8)$ mice compared to [-/-] controls. In all panels, the control group is identical (male $n=16$, female $n=5)$. Sex differences of $[\mathrm{CA} / \mathrm{H}],[\mathrm{CA} /-],[-/ \mathrm{H}],[-/-](\mathrm{G}, \mathrm{H}, \mathrm{I}$ and J, respectively). Significances of two-way ANOVA and Bonferroni-corrected post hoc $t$-test are presented as $*(*=p<0.05, * *=p<0.01, * * *=p<0.001)$. The data are presented as the means $\pm \mathrm{SEM}$. $[\mathrm{CA} / \mathrm{H}]=$ mice with carotid artery ligation and exposure to hypoxia, $[\mathrm{CA} /-]=$ mice with carotid artery ligation only, $[-/ H]=$ mice with exposure to hypoxia only, $[-/-]=$ control group, not exposed to any insult. 


\section{COMPARED WITH - / -}
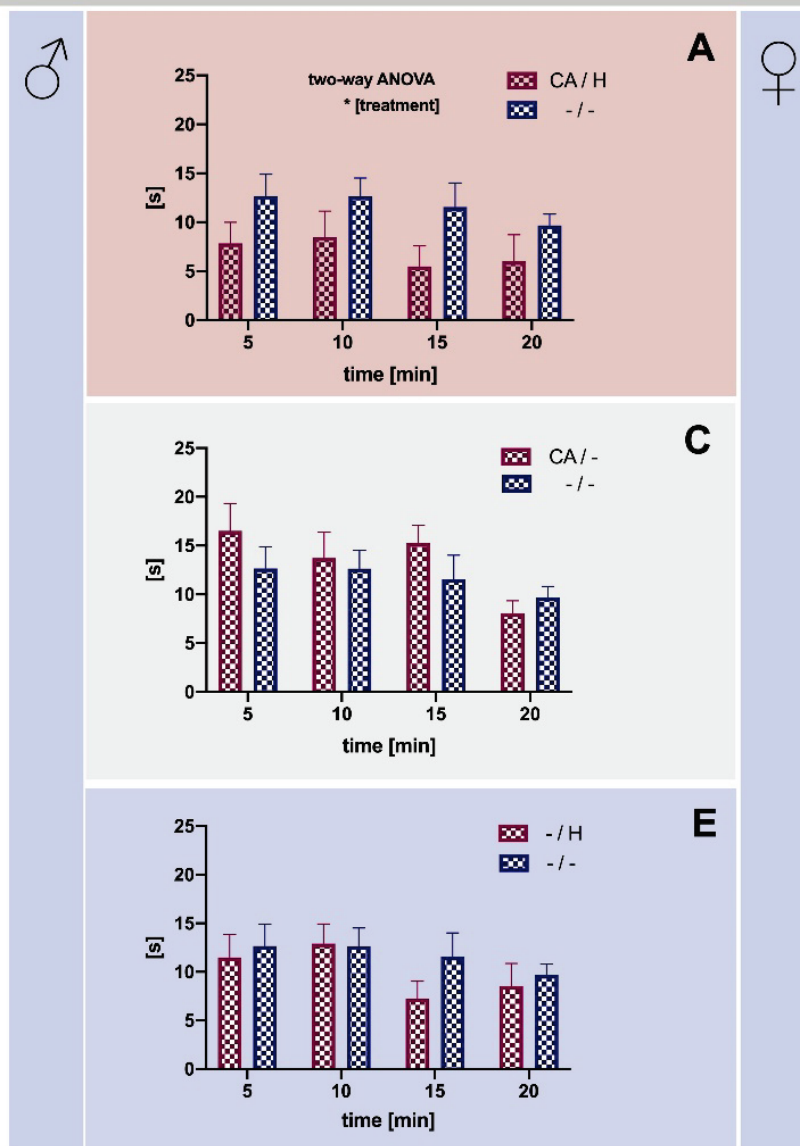

C

E

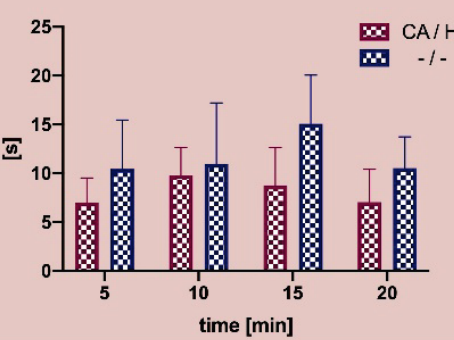

B
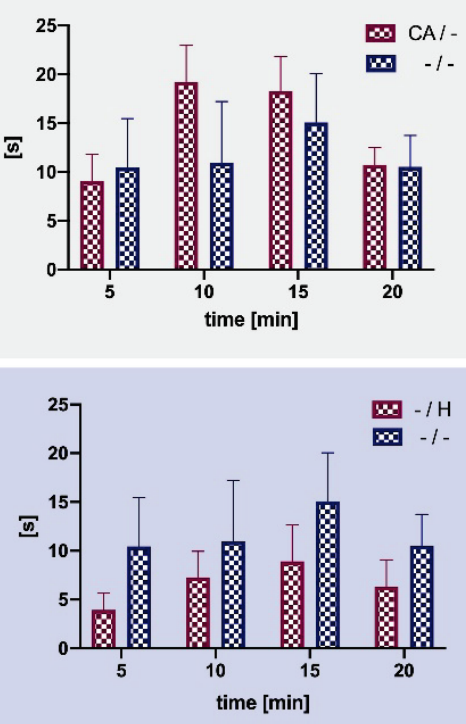

\section{SEX DIFFERENCES}
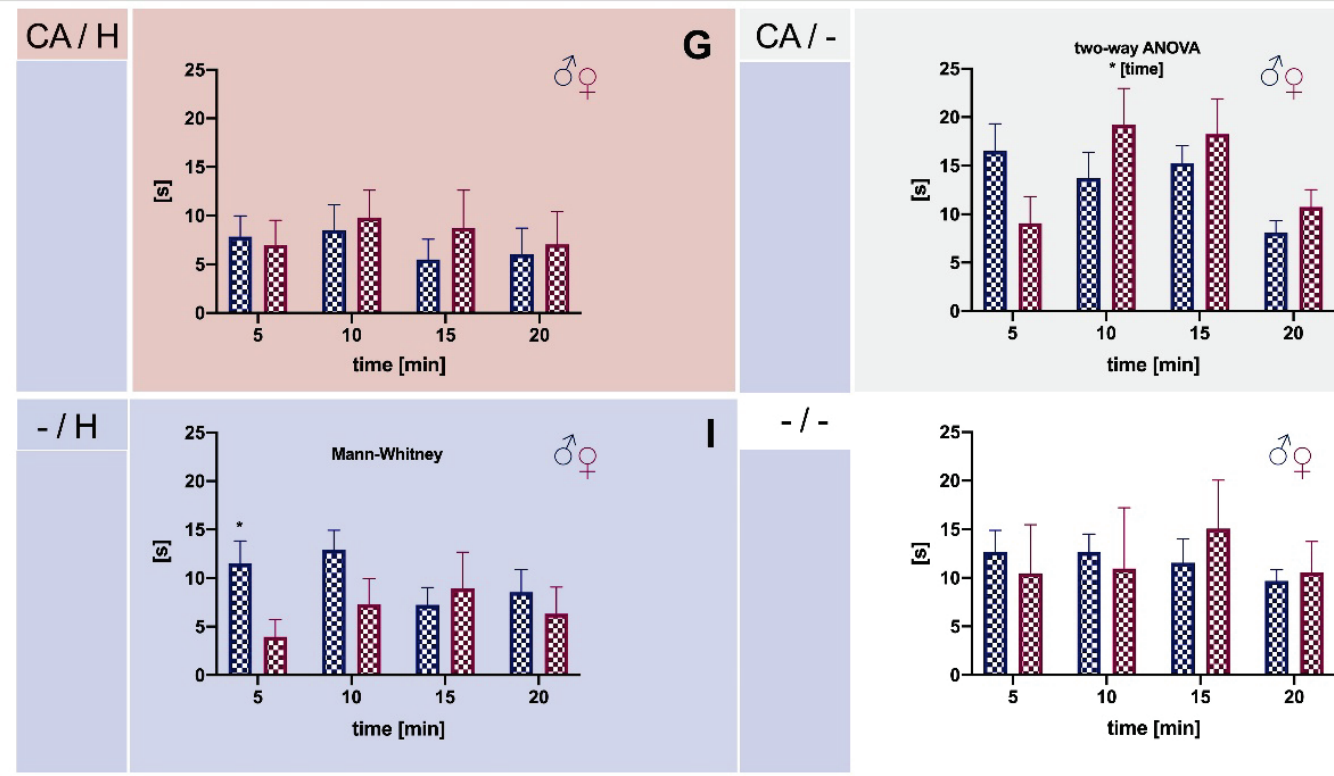

H

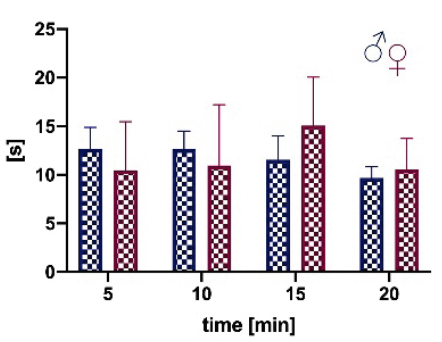

Fig. 2. Effect of early postnatal hypoxia and carotid artery ligation on rearing activity in mice in the open field test. Panels $\mathbf{A}, \mathbf{B}, \mathbf{C}, \mathbf{D}$, $\mathbf{E}, \mathbf{F}, \mathbf{G}, \mathbf{H}, \mathbf{I}$ and $\mathbf{J}$ show rearing duration in a particular 20-minute interval. $[\mathrm{CA} / \mathrm{H}]$ male $(\mathrm{A}: \mathrm{n}=4)$ and female $(\mathrm{B}: \mathrm{n}=7)$ mice compared to $[-/-]$ controls. [CA/-] male $(C: n=8)$ and female $(D: n=7)$ mice compared to $[-/-]$ controls. $[-/ H]$ male $(E: n=14)$ and female $(F: n=8)$ mice compared to [-/-] controls. In all panels, the control group is identical (male $n=16$, female $n=5$ ). Sex differences of $[C A / H]$, [CA/- ], $[-/ H],[-/-](G, H, I$ and J, respectively). Significances of two-way ANOVA, Bonferroni-corrected post hoc $t$-test and Mann-Whitney $U$ test are presented as $*(*=p<0.05, * *=p<0.01, * * *=p<0.001)$. The data are presented as the means $\pm \mathrm{SEM}$. $[\mathrm{CA} / \mathrm{H}]=$ mice with carotid artery ligation and exposure to hypoxia, $[\mathrm{CA} /-]=$ mice with carotid artery ligation only, $[-/ \mathrm{H}]=$ mice with exposure to hypoxia only, $[-/-]=$ control group, not exposed to any insult. 


\section{COMPARED WITH - / -}

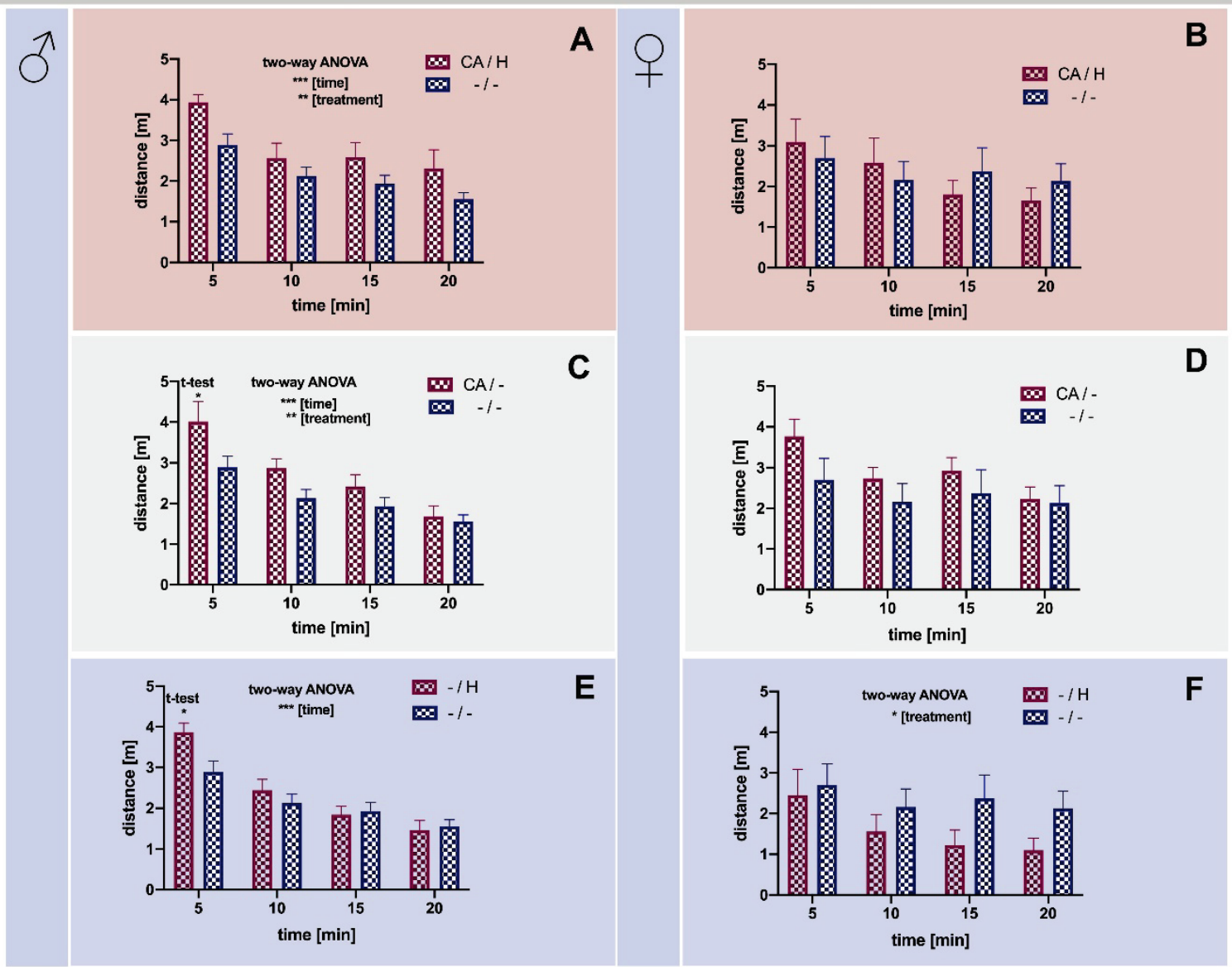

\section{SEX DIFFERENCES}
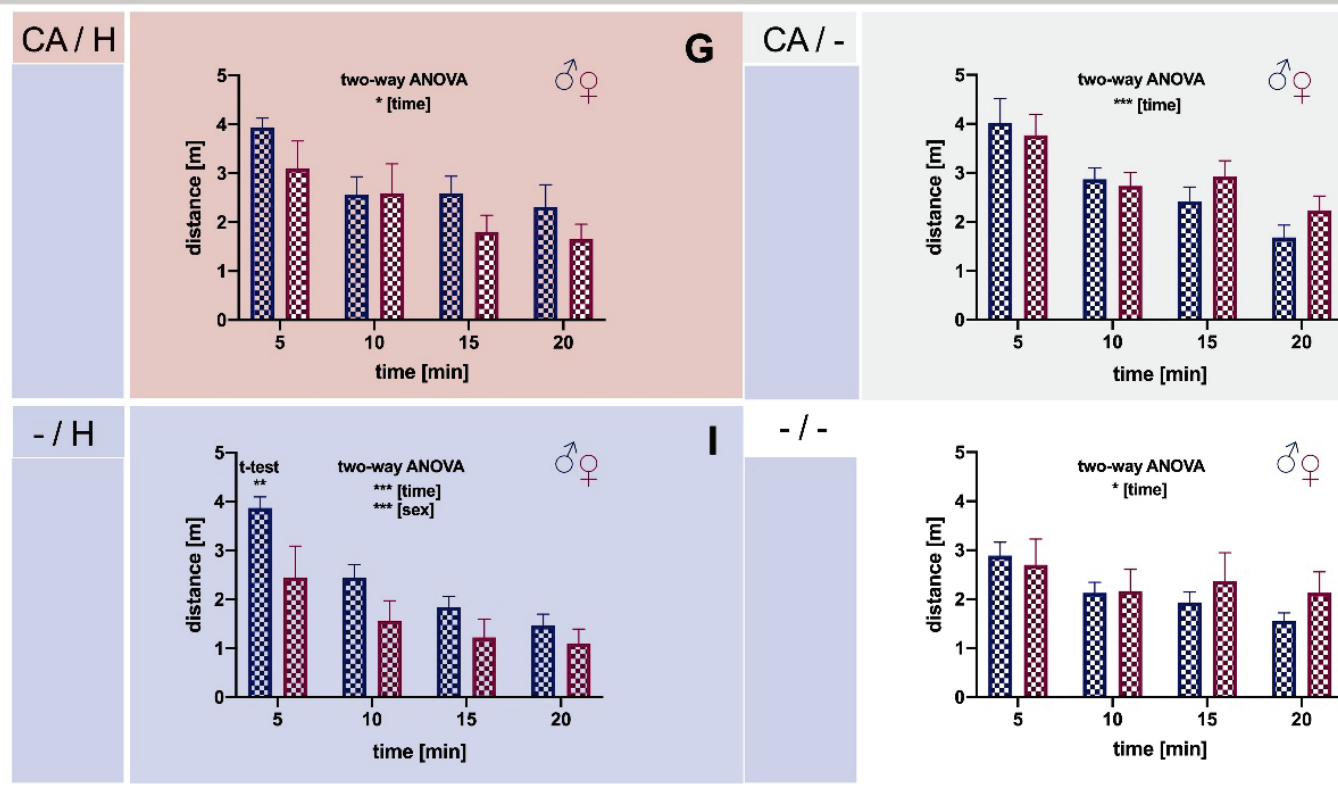

H

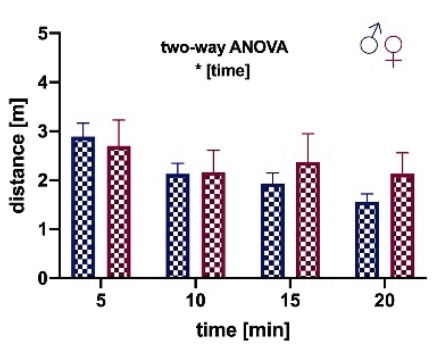

Fig. 3. Effect of early postnatal hypoxia and carotid artery ligation on travelled distance in mice in the open field test. Panels $\mathbf{A}, \mathbf{B}, \mathbf{C}$, $\mathbf{D}, \mathbf{E}, \mathbf{F}, \mathbf{G}, \mathbf{H}, \mathbf{I}$ and $\mathbf{J}$ show travelled distance in a particular 20-minute interval. $[C A / H]$ male $(A: n=4)$ and female $(B: n=7)$ mice compared to $[-/-]$ controls. [CA/-] male $(C: n=8)$ and female $(D: n=7)$ mice compared to [-/-] controls. $[-/ H]$ male $(E: n=14)$ and female ( $F: n=8)$ mice compared to [-/-] controls. In all panels, the control group is identical (male $n=16$, female $n=5$ ). Sex differences of $[\mathrm{CA} / \mathrm{H}],[\mathrm{CA} /-\mathrm{-},[-/ \mathrm{H}],[-/-](\mathrm{G}, \mathrm{H}, \mathrm{I}$ and $\mathrm{J}$, respectively). Significances of two-way ANOVA and Bonferroni-corrected post hoc $t$-test are presented as $*(*=p<0.05, * *=p<0.01, * * *=p<0.001)$. The data are presented as the means $\pm \mathrm{SEM}$. $[\mathrm{CA} / \mathrm{H}]=$ mice with carotid artery ligation and exposure to hypoxia, $[\mathrm{CA} /-]=$ mice with carotid artery ligation only, $[-/ \mathrm{H}]=$ mice with exposure to hypoxia only, $[-/-]=$ control group, not exposed to any insult. 
$(\mathrm{p}<0.001)$ and sex $(\mathrm{p}<0.001)$ were observed in the [-/H] group. Bonferroni-corrected post hoc $t$-test revealed a significantly longer travelled distance in $[-/ \mathrm{H}]$ males between the $1^{\text {st }}$ and $5^{\text {th }}$ min of the open field test $(\mathrm{p}<0.01)$ (Fig. 3I). Two-way ANOVA revealed a significant effect on time in the $[-/-]$ group $(\mathrm{p}<0.05)$ (Fig. 3J).

Males of the $[\mathrm{CA} / \mathrm{H}]$ group spent less time climbing compared to controls [-/-]: Two-way ANOVA revealed a significant effect of treatment in $[\mathrm{CA} / \mathrm{H}]$ males $(\mathrm{p}<0.05)$ (Fig. 4A). Female mice of all three target groups $[\mathrm{CA} / \mathrm{H}, \mathrm{CA} /-,-/ \mathrm{H}]$ climbed more than males: Two-way ANOVA revealed a significant effect of sex in the $[\mathrm{CA} / \mathrm{H}, \mathrm{CA} /-,-\mathrm{H}]$ groups $(\mathrm{p}<0.05)($ Fig. 4G-I).

\section{Histological analyses}

The observed areas were the cerebral cortex, CA1 and CA 3 regions of the hippocampus, hilus, and the dorsal and ventral blades of the dentate gyrus. Structural damage restricted to the hemisphere ipsilateral to the ligation was observed in the $[\mathrm{CA} / \mathrm{H}]$ group. The pathological alterations were characterized by a large number of pyknosis and nuclear fragmentation. The Nissl body was blurred with vacuolation and disordered formation of a network. Morphological features included a disordered arrangement of the cells, disappearance of the nucleus and significant loss in volume. There was an apparent cell loss and normal pyramidal cells were scattered within the background of the dead cells.

No signs of neuronal degeneration or apoptosis within the examined areas of the brain were confirmed in the $[\mathrm{CA} /-],[-/ \mathrm{H}]$ and [-/-] groups. Normal hippocampal cells were large and arranged in neat rows. Nissl bodies were deeply stained. Morphology of the cells was clear and complete with clearly visible nucleoli. Nissl bodies were equally distributed around the nucleus without cavitation (Fig. 5).

\section{Discussion}

Our study examined the long-term behavioral impact of neonatal HI brain injury and sex differences in the C57BL/6NTac mouse strain. The present study assessed:

1) The relevancy of the Rice-Vannucci model in 7-day-old C57BL/6NTac mouse pups;

2) Structural damage to the hippocampus induced by normobaric hypoxia or unilateral ligation of the common carotid artery (if delivered separately);

3) Hypoxia-ischemia-induced changes in behavioral domains, such as spontaneous climbing, in later life; and
4) The sex-dependency of behavioral and morphological differences.

Numerous models of neonatal hypoxia-ischemia were presented (Gennaro et al. 2019, Rumajogee et al. 2016), one of which is the Rice-Vannucci (RV) model. The development of a reliable model of human infant HI injury strongly relies on the ability to capture the resemblance in corticospinal system function and development in different animals (Clowry et al. 2014). A major disadvantage of different animal models is the high variability in the extent and severity of hypoxiaischemia-induced brain damage between animal species (Gennaro et al. 2019). The RV model is the most promising model in the field of neonatal hypoxiaischemia because it reproduces brain damage patterns and motor deficits similar to humans (Rumajogee et al. 2016).

Hypoxia and ischemia (i.e. the RV model of unilateral carotid artery ligation and hypoxia induction) was used, adjusted and adapted to 7-day-old C57BL/6NTac mice (Ditelberg et al. 1996, Rice et al. 1981, Zhu et al. 2009). The expected unilateral structural damage was detected in the observed areas of the brain (Rice et al. 1981, Zhu et al. 2009). An appropriate technical approach confirmed no significant morphological damage in groups with only hypoxia induction or only unilateral artery ligation, i.e. no neural impairment within the examined areas of the brain (Ten et al. 2003, Vannucci and Hagberg 2004). This finding supports the hypothesis that the combination of hypoxia and unilateral ligation ( $\mathrm{RV}$ model) is required to successfully observe morphological manifestations of HI brain injury (Rice et al. 1981, Riljak et al. 2020, Vannucci and Hagberg 2004). However, separate insults still produced changes in the spontaneous behavior of the mice. Therefore, one of the important outcomes of our study is that we cannot only emphasize morphological observations, and we must assess behavioral changes in laboratory mice. Our model indicates that the importance of behavioral testing is irreplaceable because mild hypoxic damage was not morphologically detectable but induced substantial behavioral changes.

The present study showed that perinatal hypoxia resulted in morphological and behavioral changes and generated sex-specific consequences in some domains (i.e. willingness to explore or immobility). The hypoxic male group explored the arena significantly more than hypoxic females (Fig. 1). A similar effect was observed in the travelled distance in the arena (Fig. 3). Hypoxic males moved two-times more than females (Fig. 1). HI males reared and climbed significantly less than 
COMPARED WITH - / -
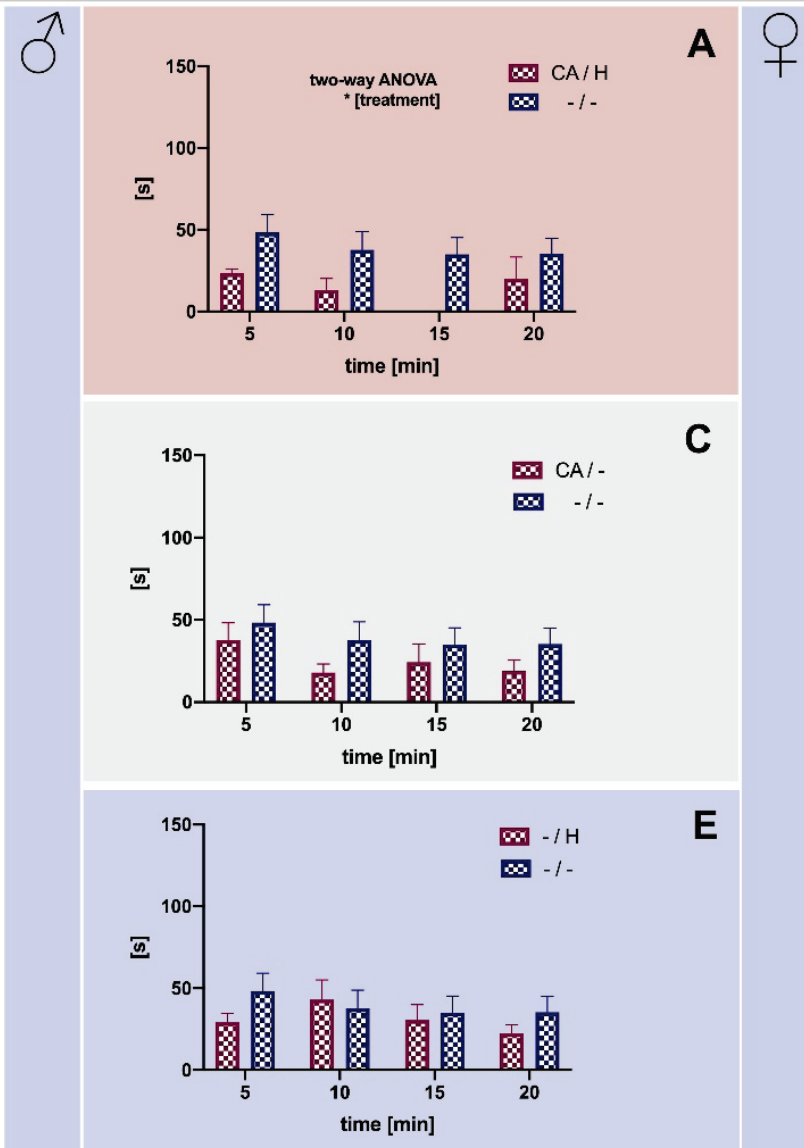

C

E

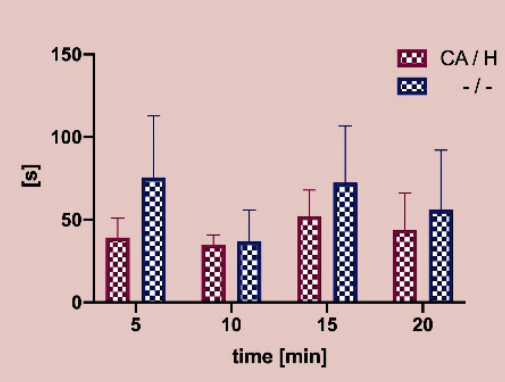

B
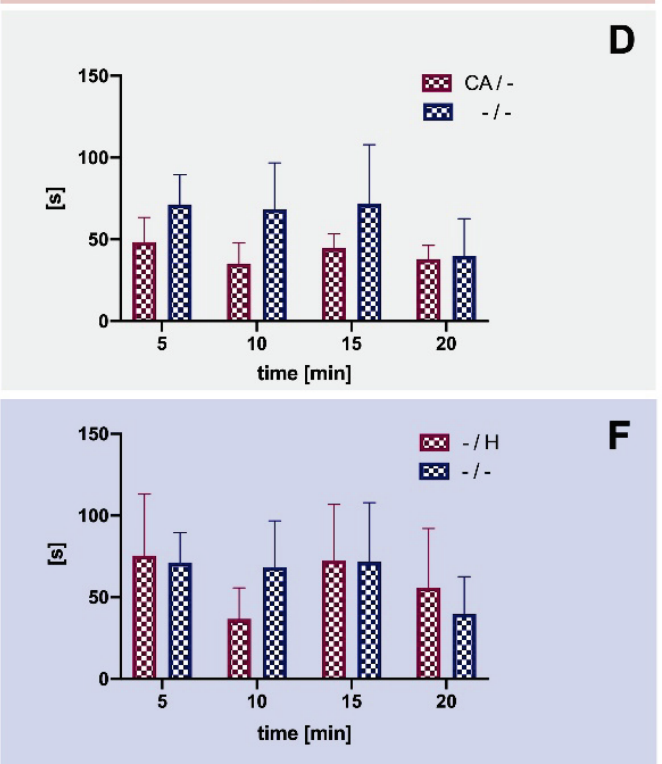

\section{SEX DIFFERENCES}
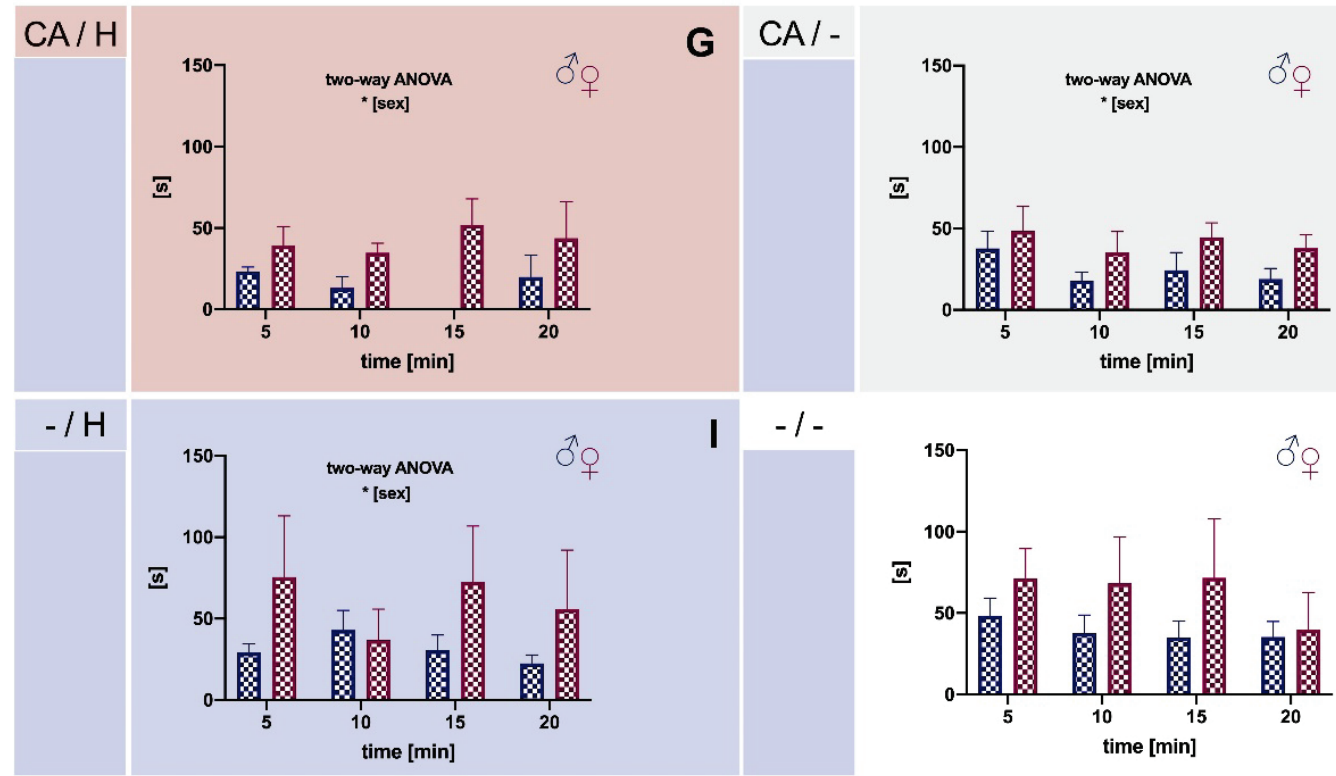

H

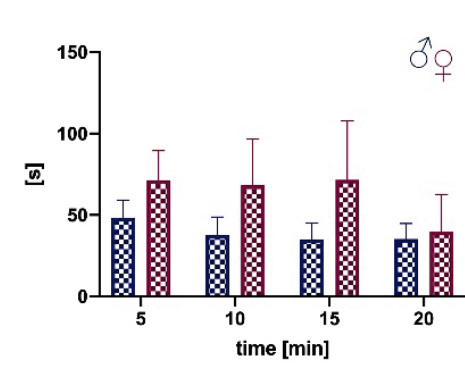

Fig. 4. Effect of early postnatal hypoxia and carotid artery ligation on climbing activity in mice in the open field test. Panels $\mathbf{A}, \mathbf{B}, \mathbf{C}, \mathbf{D}$, $\mathbf{E}, \mathbf{F}, \mathbf{G}, \mathbf{H}, \mathbf{I}$ and $\mathbf{J}$ show climbing duration in a particular 20-minute interval. $[C A / H]$ male $(A: n=4)$ and female $(B: n=7)$ mice compared to [-/-] controls. [CA/-] male $(C: n=8)$ and female $(D: n=7)$ mice compared to [-/-] controls. $[-/ H]$ male $(E: n=14)$ and female $(F: n=8)$ mice compared to $[-/-]$ controls. In all panels, the control group is identical (male $n=16$, female $n=5)$. Sex differences of $[\mathrm{CA} / \mathrm{H}],[\mathrm{CA} /-],[-/ \mathrm{H}],[-/-](\mathrm{G}, \mathrm{H}, \mathrm{I}$ and $\mathrm{J}$, respectively). Significances of two-way ANOVA and Bonferroni-corrected post hoc $t$-test are presented as $*(*=p<0.05, * *=p<0.01, * * *=p<0.001)$. The data are presented as the means $\pm \mathrm{SEM}$. $[\mathrm{CA} / \mathrm{H}]=$ mice with carotid artery ligation and exposure to hypoxia, $[\mathrm{CA} /-]=$ mice with carotid artery ligation only, $[-/ \mathrm{H}]=$ mice with exposure to hypoxia only, $[-/-]=$ control group, not exposed to any insult. 


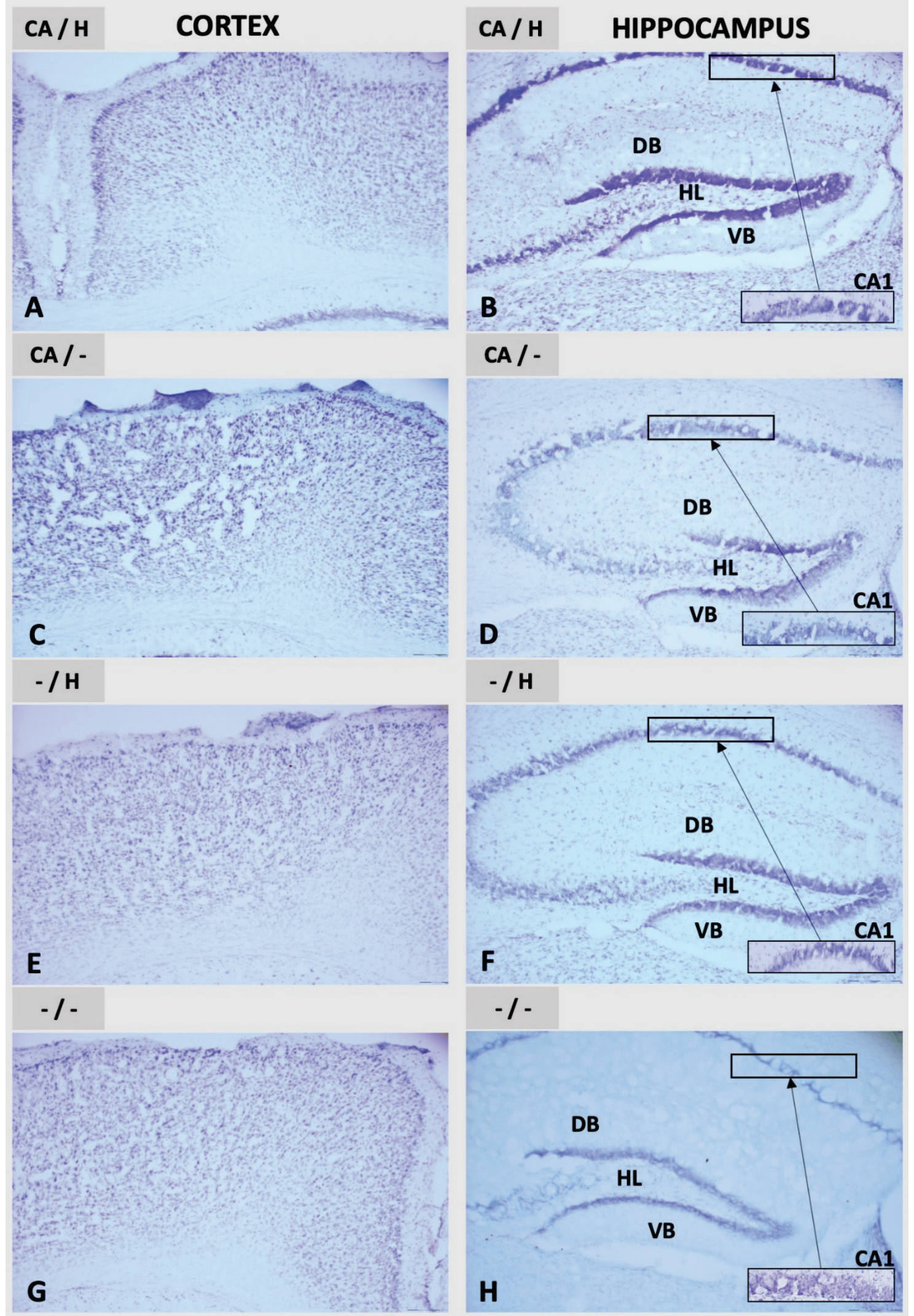

Fig. 5. Representative stereomicroscopic photographs of male mouse brain sections from the four experimental groups, Nissl stained. Cortex and hippocampus of the hemisphere ipsilateral to the ligation $(\mathbf{A}, \mathbf{B}, \mathbf{C}, \mathbf{D}, \mathbf{E}, \mathbf{F}, \mathbf{G}$, scale bar: $500 \mu \mathrm{m})$, with magnification of the CA1 zone (scale bar: $200 \mu \mathrm{m})$. In groups $[-/-],[-/ H],[C A /-],(\mathbf{C}, \mathbf{D}, \mathbf{E}, \mathbf{F}, \mathbf{G}$ and $\mathbf{H}$, respectively), there is no visible morphological damage to the hippocampus or cortex. In the $[\mathrm{CA} / \mathrm{H}]$ group $(\mathbf{A}, \mathbf{B}$, respectively), there is visible atrophy and loss of brain tissue. $[\mathrm{CA} / \mathrm{H}]=$ mice with carotid artery ligation and exposure to hypoxia, $[\mathrm{CA} /-]=$ mice with carotid artery ligation only, $[-/ H]=$ mice with exposure to hypoxia only, $[-/-]=$ control group, not exposed to any insult. 
controls (Figs 2 and 4). The open field test showed that all three target male groups (hypoxic, ischemic and HI) explored the test arena significantly more than controls in the first five minutes (Fig. 1). Males in general showed higher sensitivity to all insults. Female mice climbed more in general, and hypoxic females reared significantly less than hypoxic males (Figs 2 and 4). Notably, the process of habituation was significantly impaired in males, and hypoxia alone decreased the willingness of female mice to explore. Males and females postnatally exposed to hypoxia-ischemia exhibited lower vertical activity (i.e. rearing and climbing) and higher horizontal activity (i.e. locomotion and travelled distance). These observations reached statistical significance in males but not females.

The above-described behavioral changes in mice exposed to hypoxia or ischemia separately are notable for many reasons. We found that female mice naturally had higher climbing activity than male mice during our observation (Fig. 4). This climbing augmented bar-related activity is a form of repetitive stereotypic-like behavior and may be understood as a higher inquisitiveness of females about the unknown environment outside of the cage (Dere et al. 2018). The gentle climbing grip may be a representation of fine motor skills, which are otherwise extremely difficult to define and study in a biological model. However, previously published studies did not focus on sex differences in climbing (Nevison et al. 1999). This natural difference between sexes may underlie some observations of insignificant behavioral changes. For example, a larger difference between females in the control and observed groups would be necessary to achieve a significant result in climbing than males.

The C57BL/6NTac mouse strain was selected for our research. Various mouse strains showed individual susceptibility to the hypoxia-ischemia-induced brain damage in the RV model (Sheldon et al. 1998, Sheldon et al. 2018, Wolf et al. 2016). The C57BL/6 mouse strain is represented by distinct sub-strains that differ genetically and phenotypically (Zhao et al. 2019). However, the C57BL/6NTac inbred strain is one of the most suitable strains, and it is widely used. This strain is an ideal candidate for gender comparison studies (Zhao et al. 2019). This mouse strain showed substantial brain damage following a relatively short exposure to an environment with decreased oxygen concentration, which enabled a prompt detection of differences in our study.
However, there are some limitations to our study. Although the RV model is a well-established and verified approach to examine hypoxia-ischemia injury to immature brain, it suffers a certain level of inconsistency. Two of the major problems are the differences between human and rodent brain organization and discrepancies in the rate of maturation (Dobbing and Sands 1979, Rumajogee et al. 2016). Rodents also have a considerably smaller proportion of sub-cortical white matter, essential differences in cerebral blood flow and metabolism and a greater susceptibility to grey matter injury in response to white matter lesions (Vannucci and Vannucci 2005). Morphological brain damage related to the RV model was only described using basic staining and morphological techniques. Therefore, more precise histological and immunohistological analyses would be appropriate. Unfortunately, we did not have the opportunity to consider the long-term influence of perinatal hypoxia, ischemia or their combination on diverse aspects of mouse spontaneous behavior. Our study is also limited by the performing of only a shortterm observation of mouse behavior. A longer observation period would provide us with valuable additional information on differences in the behavioral spectrum and prolonged consequences of the experiment. We did not analyze changes in mice behavior during the daytime and behavioral changes during the dark (active) phase of the circadian rhythm. Specific behavioral domains of mice differ markedly throughout the day (Valuskova et al. 2019). During the behavioral testing of laboratory rodents, various external factors (e.g. physical factors, timing or presence of the investigator, light, noise) may be a source of bias (Dere et al. 2018, Perals et al. 2017). Therefore, the present study sought to minimize confounding external factors with the use of the automated LABORAS system, which allows evaluations of the spontaneous behavior of mice without the presence of an observer (Van de Weerd et al. 2001).

In conclusion, the observed alterations in the spontaneous behavior of C57BL/6NTac mice were not accompanied by morphological changes in groups with separately induced hypoxia or ischemia. Nevertheless, the isolated insults significantly influenced the spontaneous behavior of these mice later in life. In contrast, hypoxia and ischemia together (RV model) induced substantial behavioral and morphological changes in C57BL/6NTac mice, which led to significant differences in behavioral profiles for habituation and the ability of mice to cope with novelty. Males and females postnatally exposed to 
hypoxia-ischemia exhibited lower vertical activity and higher horizontal activity. This observation only reached statistical significance in males likely because of natural differences between the sexes. Female mice naturally climbed more, and hypoxic females reared significantly less than hypoxic males. This study suggests that differences between horizontal and vertical activity in reaction to hypoxia-ischemia deserve more attention in future studies and that both genders should be considered separately in future hypoxia studies. Different animal models, long-term consequences, diurnal rhythm and more precise imaging should also be considered.

Our main aim was to revise and understand the pathophysiological mechanisms and complexity of the hypoxic process in the brain. We believe this understanding will provide a great start for future studies and open the path for the discovery or possible therapeutic interventions.

\section{Conflict of Interest}

There is no conflict of interest.

\section{Acknowledgements}

The study was supported by the Charles University, project GA UK No 454218 and the research programs PROGRES Q35 and Q25.

\section{References}

BISWAL S, SHARMA D, KUMAR K, NAG TC, BARHWAL K, HOTA SK, KUMAR B: Global hypoxia induced impairment in learning and spatial memory is associated with precocious hippocampal aging. Neurobiol Learn Mem 133: 157-170, 2016. https://doi.org/10.1016/j.nlm.2016.05.011

BORBÉLYOVÁ V, JANIŠOVÁ K, MYSLIVEČEK J, RILJAK V: Sex-related differences in locomotion and climbing of C57Bl/6NTac mice in a novel environment. Physiol Res 68 (Suppl 3): S353-S359, 2019. https://doi.org/10.33549/physiolres.934348

CLOWRY GJ, BASUODAN R, CHAN F: What are the best animal models for testing early intervention in cerebral palsy? Front Neurol 5: 258, 2014. https://doi.org/10.3389/fneur.2014.00258

COLVER A, FAIRHURST C, PHAROAH PO: Cerebral palsy. Lancet 383: 1240-1249, 2014. https://doi.org/10.1016/S0140-6736(13)61835-8

DAVIDSON JO, WASSINK G, VAN DEN HEUIJ LG, BENNET L, GUNN AJ: Therapeutic hypothermia for neonatal hypoxic-ischemic encephalopathy-where to from here? Front Neurol 6: 198, 2015. https://doi.org/10.3389/fneur.2015.00198

DERE E, RONNENBERG A, TAMPE B, ARINRAD S, SCHMIDT M, ZEISBERG E, EHRENREICH H: Cognitive, emotional and social phenotyping of mice in an observer-independent setting. Neurobiol Learn Mem 150: 136-150, 2018. https://doi.org/10.1016/j.nlm.2018.02.023

DERRICK M, ENGLOF I, DROBYSHEVSKY A, LUO K, YU L, TAN S: Intrauterine fetal demise can be remote from the inciting insult in an animal model of hypoxia-ischemia. Pediatr Res 72: 154-160, 2012. https://doi.org/10.1038/pr.2012.65

DITELBERG JS, SHELDON RA, EPSTEIN CJ, FERRIERO DM: Brain injury after perinatal hypoxia-ischemia is exacerbated in copper/zinc superoxide dismutase transgenic mice. Pediatr Res 39: 204-208, 1996. https://doi.org/10.1203/00006450-199602000-00003

DOBBING J, SANDS J: Comparative aspects of the brain growth spurt. Early Hum Dev 3: 79-83, 1979. https://doi.org/10.1016/0378-3782(79)90022-7

DOUGLAS-ESCOBAR M, WEISS MD: Hypoxic-ischemic encephalopathy: a review for the clinician. JAMA Pediatr 169: 397-403, 2015. https://doi.org/10.1001/jamapediatrics.2014.3269

GENNARO M, MATTIELLO A, PIZZORUSSO T: Rodent models of developmental ischemic stroke for translational research: strengths and weaknesses. Neural Plast 2019: 5089321, 2019. https://doi.org/10.1155/2019/5089321

HAGBERG H, EDWARDS AD, GROENENDAAL F: Perinatal brain damage: the term infant. Neurobiol Dis 92 : 102-112, 2016. https://doi.org/10.1016/j.nbd.2015.09.011

HILL CA, FITCH RH: Sex differences in mechanisms and outcome of neonatal hypoxia-ischemia in rodent models: implications for sex-specific neuroprotection in clinical neonatal practice. Neurol Res Int 2012: 867531, 2012. https://doi.org/10.1155/2012/867531 
HUANG HZ, WEN XH, LIU H: Sex differences in brain MRI abnormalities and neurodevelopmental outcomes in a rat model of neonatal hypoxia-ischemia. Int J Neurosci 126: 647-657, 2016. https://doi.org/10.3109/00207454.2015.1047016

JOHNSTON MV, HAGBERG H: Sex and the pathogenesis of cerebral palsy. Dev Med Child Neurol 49: 74-78, 2007. https://doi.org/10.1017/S0012162207000199.x

LAN WC, PRIESTLEY M, MAYORAL SR, TIAN L, SHAMLOO M, PENN AA: Sex-specific cognitive deficits and regional brain volume loss in mice exposed to chronic, sublethal hypoxia. Pediatr Res 70: 15-20, 2011. https://doi.org/10.1203/PDR.0b013e31821b98a3

LIU L, OZA S, HOGAN D, PERIN J, RUDAN I, LAWN JE, COUSENS S, MATHERS C, BLACK RE: Global, regional, and national causes of child mortality in 2000-13, with projections to inform post-2015 priorities: an updated systematic analysis. Lancet 385: 430-440, 2015. https://doi.org/10.1016/S0140-6736(14)61698-6

MURDEN S, BORBÉLYOVÁ V, LAŠTU゚VKA Z, MYSLIVEČEK J, OTÁHAL J, RILJAK V: Gender differences involved in the pathophysiology of the perinatal hypoxic-ischemic damage. Physiol Res 68 (Suppl 3): S207-S217, 2019. https://doi.org/10.33549/physiolres. 934356

NEVISON CM, HURST JL, BARNARD CJ: Why do male ICR(CD-1) mice perform bar-related (stereotypic) behaviour? Behav Processes 47: 95-111, 1999. https://doi.org/10.1016/S0376-6357(99)00053-4

NORTHINGTON FJ: Brief update on animal models of hypoxic-ischemic encephalopathy and neonatal stroke. ILAR J 47: 32-38, 2006. https://doi.org/10.1093/ilar.47.1.32

PERALS D, GRIFFIN AS, BARTOMEUS I, SOL D: Revisiting the open-field test: what does it really tell us about animal personality? Anim Behav 123: 69-79, 2017. https://doi.org/10.1016/j.anbehav.2016.10.006

PERLMAN JM, WYLLIE J, KATTWINKEL J, ATKINS DL, CHAMEIDES L, GOLDSMITH JP, GUINSBURG R, HAZINSKI MF, MORLEY C, RICHMOND S, SIMON WM, SINGHAL N, SZYLD E, TAMURA M, VELAPHI S: Part 11: neonatal resuscitation: 2010 International consensus on cardiopulmonary resuscitation and emergency cardiovascular care science with treatment recommendations. Circulation 122 (16 Suppl 2): S516-S538, 2010. https://doi.org/10.1161/CIRCULATIONAHA.110.971127

PIETROPAOLO S, MINTZ M, FELDON J, YEE BK: The behavioral sequela following the prevention of home-cage grid-climbing activity in C57BL/6 mice. Behav Neurosci 121: 345-355, 2007. https://doi.org/10.1037/07357044.121.2.345

RICE JE 3RD, VANNUCCI RC, BRIERLEY JB: The influence of immaturity on hypoxic-ischemic brain damage in the rat. Ann Neurol 9: 131-141, 1981. https://doi.org/10.1002/ana.410090206

RILJAK V, KRAF J, DARYANANI A, JIRUŠKA P, OTÁHAL J: Pathophysiology of perinatal hypoxic-ischemic encephalopathy - biomarkers, animal models and treatment perspectives. Physiol Res 65 (Suppl 5): S533-S545, 2016. https://doi.org/10.33549/physiolres.933541

RILJAK V, LAŠTŮVKA Z, MYSLIVEČEK J, BORBÉLYOVÁ V, OTÁHAL J: Early postnatal hypoxia induces behavioral deficits but not morphological damage in the hippocampus in adolescent rats. Physiol Res 69: 165-179, 2020. https://doi.org/10.33549/physiolres. 934234

RUMAJOGEE P, BREGMAN T, MILLER SP, YAGER JY, FEHLINGS MG: Rodent hypoxia-ischemia models for cerebral palsy research: a systematic review. Front Neurol 7: 57, 2016. https://doi.org/10.3389/fneur.2016.00057

SANCHES EF, ARTENI N, NICOLA F, ARISTIMUNHA D, NETTO CA: Sexual dimorphism and brain lateralization impact behavioral and histological outcomes following hypoxia-ischemia in P3 and P7 rats. Neuroscience 290: 581-593, 2015. https://doi.org/10.1016/j.neuroscience.2014.12.074

SHELDON RA, SEDIK C, FERRIERO DM: Strain-related brain injury in neonatal mice subjected to hypoxiaischemia. Brain Res 810: 114-122, 1998. https://doi.org/10.1016/S0006-8993(98)00892-0

SHELDON RA, WINDSOR C, FERRIERO DM: Strain-related differences in mouse neonatal hypoxia-ischemia. Dev Neurosci 40: 490-496, 2018. https://doi.org/10.1159/000495880

SHETTY J: Neonatal seizures in hypoxic-ischaemic encephalopathy--risks and benefits of anticonvulsant therapy. Dev Med Child Neurol 57: 40-43, 2015. https://doi.org/10.1111/dmen.12724

TAGIN M, ABDEL-HADY H, UR RAHMAN S, AZZOPARDI DV, GUNN AJ: Neuroprotection for perinatal hypoxic ischemic encephalopathy in low- and middle-income countries. J Pediatr 167: 25-28, 2015. https://doi.org/10.1016/j.jpeds.2015.02.056 
TEN VS, BRADLEY-MOORE M, GINGRICH JA, STARK RI, PINSKY DJ: Brain injury and neurofunctional deficit in neonatal mice with hypoxic-ischemic encephalopathy. Behav Brain Res 145: 209-219, 2003. https://doi.org/10.1016/S0166-4328(03)00146-3

VALUSKOVA P, RILJAK V, FORCZEK ST, FARAR V, MYSLIVECEK J: Variability in the drug response of M(4) muscarinic receptor knockout mice during day and night time. Front Pharmacol 10: 237-237, 2019. https://doi.org/10.3389/fphar.2019.00237

VAN DE WEERD HA, BULTHUIS RJ, BERGMAN AF, SCHLINGMANN F, TOLBOOM J, VAN LOO PL, REMIE R, BAUMANS V, VAN ZUTPHEN LF: Validation of a new system for the automatic registration of behaviour in mice and rats. Behav Processes 53: 11-20, 2001. https://doi.org/10.1016/S0376-6357(00)00135-2

VANNUCCI RC, VANNUCCI SJ: Perinatal hypoxic-ischemic brain damage: evolution of an animal model. Dev Neurosci 27: 81-86, 2005. https://doi.org/10.1159/000085978

VANNUCCI SJ, HAGBERG H: Hypoxia-ischemia in the immature brain. J Exp Biol 207: 3149-3154, 2004. https://doi.org/10.1242/jeb.01064

WOLF S, HAINZ N, BECKMANN A, MAACK C, MENGER MD, TSCHERNIG T, MEIER C: Brain damage resulting from postnatal hypoxic-ischemic brain injury is reduced in $\mathrm{C} 57 \mathrm{BL} / 6 \mathrm{~J}$ mice as compared to C57BL/6N mice. Brain Res 1650: 224-231, 2016. https://doi.org/10.1016/j.brainres.2016.09.013

ZHAO L, MULLIGAN MK, NOWAK TS JR: Substrain- and sex-dependent differences in stroke vulnerability in C57BL/6 mice. J Cereb Blood Flow Metab 39: 426-438, 2019. https://doi.org/10.1177/0271678X17746174

ZHU C, WANG X, BLOMGREN K: Cerebral hypoxia-ischemia in neonatal rats or mice: a model of perinatal brain injury. In: Animal Models of Acute Neurological Injuries. CHEN J, XU ZC, XU XM, ZHANG JH (eds), Humana Press, Totowa, 2009, pp 221-230. https://doi.org/10.1007/978-1-60327-185-1_18 